\title{
How Can Cinema Justify Wars? A Qualitative Study on War Justification in American Cinema
}

\author{
Zahra Emamzadeh $^{1} \&$ Shaho Sabbar ${ }^{1}$ \\ ${ }^{1}$ University of Tehran, Faculty of World Studies, Iran \\ Correspondence: Shaho Sabbar, University of Tehran, Faculty of World Studies, Iran. E-mail: \\ shaho_sabbar@yahoo.com
}

Received: September 4, 2016

Accepted: October 2, 2016 Online Published: December 29, 2016

doi:10.5539/jpl.v10n1p18

URL: http://dx.doi.org/10.5539/jpl.v10n1p18

\begin{abstract}
Cinema is a powerful media that can shape people's minds about different issues. Movies can focus on very detailed or hidden matters in society, and critical issues that profoundly affect the lives of large populations are usually at the center of cinema's attention. Among these issues are wars that can affect tens of millions of people financially, mentally and of course physically.

Films can question or justify wars. To answer if they questioned wars or justified them one should choose a specific war, a period and maybe a particular group of films and analyze their content and discourse. However, to do so, it would be helpful and maybe necessary to first better understand how films may question or justify wars.

The present research is an effort to analyze a specific number of movies to see in what ways they may have justified the role of the United States in the Second World War. The results include eight issues that the movies raised regarding the legitimacy of the war and America's role in it.
\end{abstract}

Keywords: Media, Legitimacy of War, American War films, World War II

\section{Introduction}

Homer, a former sailor who lost both his arms in the Second World War and now he uses metal hook prostheses, is sitting in a bar when a stranger tells him he sacrificed his arms fighting the wrong people. Homer gets into a fight with him, and his friend, another veteran of the war, punches the stranger in the face and knocks him down to the floor.

One can consider the question of the legitimacy of war as the most long-lasting problem in the case of most wars. Sometimes it becomes the main issue long before the war, begins when the governments and political parties try to legitimize the war, and it remains a major problem long after the war is over as the social activists, politicians, historians and others keep talking about it.

War legitimacy can be seen as an example of the connection between politics and war (Chester, 2000). The importance of legitimacy of war and how it affects democracies has been the concern of many studies (Bergen, 2001; Fabre, 2008; Kumm, 2004; Ramsbotham \& Wennmann, 2014; Mueller, 2005).

Wars are expensive and mostly destructive. Also, the risk of failure is more or less involved. Other than the concerns for what may happen to a country, there are usually humanitarian concerns about what it may do to the other side of the war.

For the above-mentioned reasons and probably other reasons, when it comes to wars and especially when a country wants to initiate or willingly take part in a war, usually a primary concern is to make the people believe that it's necessary or may be inevitable to do so. That may be true even with dictatorships (Rothstein, 2009; Gillespie, 2006; Falomir-Pichastor, Staerklé, Pereira, \&Butera, 2012; Crawford, 2016).

In fact, Legitimacy plays a critical role in the fate of countries and their actions in the international sphere. Many years after the U.S. dropped two nuclear bombs on Hiroshima and Nagasaki, killing tens of thousands of people, debates on the legitimacy of the actions are still alive. However, Washington, as the only government in human history that has used nuclear bombs, has somehow managed to be an international police, preventing other countries (at least some others) from acquiring atomic bombs.

When the U.S. representatives speak at the United Nations, advocating more pressure on Iran, North Korea or 
other countries due to their alleged efforts to develop nuclear capabilities, most countries seem to accept that America can have the role of international police on this issue.

Polls show that most Americans believe America is justified to bomb Iran to prevent it from becoming a nuclear-capable nation (Agiesta, 2015). They may even believe it to be an action to save humanity. It seems that the U.S. has been incomparably more successful than North Korea and Iran to legitimize its actions in the international arena.

It's obvious that countries like Iran and North Korea are nowhere near where the U.S. stands regarding financial, political and military power and clearly, that power affects the results of a country's negotiation. The issues of legitimacy and bargaining power cannot be reduced to what the media do. However, a country's success in legitimizing its actions should be studied by considering its different means and aspects.

In this research to shed a partial light on some aspects of the issue, this study will limit itself to studying films as a tool a nation may use to advocate its legitimacy to take part in wars. A practical tool (if not the only one) to affect people's opinions (if not shape them) are media (Hadeshian, 2006; Baum \& Potter, 2008; Entman, 2004).

Among different media, cinema is known for its social power (Rastegar, 2015). Movies can affect people's opinions. Maybe films are unique in this regard for being individually memorable, as Lynch says television movies are the second draft of public memory, the first being journalism (Rastegar, 2015; Lynch, 2007).

This paper is an effort to study, the ways that movies may work to legitimize a war. We will do so by analyzing nine American war movies of a particular time and examine how they addressed the role of the United States in WWII.

Since this is a qualitative study, we do not intend to reach a generalizable conclusion on whether or not American cinema tried to legitimize or question the United States' actions in the war. Rather, we will try to investigate the likely ways that a movie and its dialogues can justify wars and the roles that some countries take on them.

\section{Problem Statement and Literature}

\subsection{Legitimacy}

Legitimacy defined as a generalized perception of social acceptance (Vergne, 2011). Many scholars have focused on legitimate entities such as legal organizations and democratic governments. For instance, Coakley argues that there are certain features that a state needs to possess to be legitimate (Coakley, 2010).

However, another aspect of the term has to deal with legitimate actions. What an action is, what its results are, who does it and other factors can play a role in how to legitimate an action is perceived to be.

Governments in democratic nations usually considered as legitimate sources of political authority. However, this does not only give them the possibility to make any decisions regardless of how public opinion might react to them.

The cost of war is a fundamental issue here. "Democracies are more sensitive to the expenses of fighting than are other types of regimes, so they are more cautious when considering the use of force and tend to fight short, low-cost wars" (Levy, 2010, p. 78).

\subsection{The Gap of Legitimacies Syndrome}

Levy suggests that western democracies have faced a problem of legitimizing the wars they are willing to take part in or initiate, especially the costly ones.He calls the issue Gap of Legitimacies Syndrome, which he describes as "widening of the gap between high levels of political legitimacy for using force and low levels of social legitimacy for making the attendant sacrifices".

Australia, Canada, and most European countries have managed the problem by limiting their use of force(Levy, 2010). The United States, however, fought all-out wars frequently. In a democracy where people's opinion can change presidents, the issue of legitimacy is naturally critical. Now, with the United States getting involved in wars all the time and people with a weak tendency to sacrifice their lives in wars the issue of legitimacy only becomes more critical.

\subsection{Manufacturing Consent}

Herman and Chomsky (1988), argue that a significant role that media play in American society is to prepare it to accept the values of the ruling elite willingly. They reject the idea that the press serves as a mean for the public to gain the information needed to have sufficient control over the politicians and the flow of power in the country. On the contrary, they believe the media's purpose is to defend the economic, social, and political agenda of privileged and dominant groups in the society (Herman \& Chomsky, 1988). 
They present an extensive discussion, including a detailed argument on several wars that America was engaged in and explain the social and organizational structures within which the U.S. media operate. They argue that the conglomerates control media of different types including motion picture studios, and they have managed to make the media internalize the values of the ruling elite (Herman \& Chomsky, 1988).

From this point of view, filling the gap of legitimacies would be an expected function of media, including cinema, either before/after the war to earn public support for the war and to facilitate mobilization of human and material resources. Or after the war to maintain the positive public opinion and prevent public hostility against the decisions and the policy makers who took the nation to war (like it happened in the case of the Vietnam War).

A similar idea about the media's role regarding legitimizing wars encourages Gerd to call them " the fourth branch of military operations" and consider them exactly as important as military power. Horton quotes from StigHjarvard to define Mediatization as a process through which a society is increasingly submitted to or becomes depended on the media (Horten, 2011).

He says the war and war reporting have been mediatized and during the Second World War its methods were developed, and new censorship flourished in the U.S. This included private media that were run on commercial advertising and in fact American propaganda was privatized. Horton argues that in the modern society, our understanding of wars is shaped by the media (Horten, 2011).

\subsection{Objectives}

Cinema, as research has indicated, can play a significant role in shaping society's understanding about different public issues. Wars are among important issues that a state may try to form public opinion about it. This study is an effort to explore, in more details, the way movies can justify wars and a country's role in them.

Filmmakers can present an argument to the audiences by choosing what questions raised in the film, how these issues answered, how different people or concepts are pictured, etc. Careful examination of the dialogues and scenes of a movie can provide us with an overall understanding of the argument that the film is presented.

In this case, we are concerned about the points that movies make regarding the legitimacy of the involvement of the United States and rightfulness of its actions in the Second World War. Our goal is to present a more detailed understanding of how movies may have addressed the issue and tried to legitimize the actions of the U.S. in the war.

Qualitative studies are usually meant to pave the way for quantitative research. Qualitative research can analyze a text and extract concepts and meanings from it to provide an organized understanding of the text. That understanding can be later used in quantitative studies to evaluate a statistically representative collection of other documents to make generalized/generalizable judgments.

In regards to the issue at hand, qualitative research can study some movies and determine the ways they pictured the war and the actions of the Americans in the war and the ways they may have tried to legitimize those actions.

The outcomes of such research could be used by scholars interested in quantitative studies to systematically examine some movies made in a particular time and make a judgment if they legitimized a specific war or specific actions of a country.

One of the commonly used methods to examine different texts is a qualitative content analysis, which is often used for analyzing qualitative data (Elo, et al., 2014). In the qualitative content analysis, the focus is on interpretation rather than quantification and the emphasis is on subjectivity rather than objectivity. In analyzing the dialogues of a movie naturally involves understanding, this study will use qualitative content analysis as its method.

Therefore, we will not be looking for a generalized answer to whether or not American cinema tried to justify the America's role and actions in the Second World War. With a qualitative approach, we are seeking a better understanding on how movies may have addressed the issue.

If we can prepare a list of questions/issues that raised and the way they were answered/explained in the movies, we may be able to provide future quantitative studies with a tool to examine the films of different time periods and evaluate their arguments.

\section{Methodology}

This study will carry out a careful examination of the dialogues of 9 movies to extract their arguments regarding the role of the United States in the Second World War. We will limit the cases to be studied to the post-war films produced between the years of 1946 to 1949 - one year after the Second World War ended until the end of the 
decade.

The research will be limited to the examination of the dialogues. Obviously, the researchers will watch the movies, and the way the talks are understood is affected by the scenes and contexts. However, the outcome of the study will be limited to texts and not an analysis of the pictures and scenes.

As far as this research was able to learn, between 1946 and 1949, nine major war-related films were made in the United States. The following is a list of the movies.

1946

1948

1948

1949
The Best Years of Our Lives

13 Rue Madeleine

Command Decision

Fighter Squadron

Battleground

Home of the Brave

Malaya

Grains of sand of Iwo Jima

Twelve O'clock High
William Wyler

Henry Hathaway

Sam Wood

Raoul Walsh

William A. Wellman

Mark Robson

Richard Thorpe

Allan Dwan

Henry King

While watching the movies, the researchers will be sensitive to any dialogue that might be related to any of the following issues:

- Any statement that justifies the legitimacy of the war in general.

- Any statement that justifies the actions of an actor involved in the war.

- Any statement that may evaluate the goodness or evilness of an actor's action in the war.

- Any statement that may evaluate the goodness or evilness of an actor's intentions.

Whenever the researcher encounters such a statement, he/she will write the exact statement down. As suggested by qualitative studies, in the first level of data-gathering, the researchers will think broad and will be sensitive to any piece of data that can be considered related to the issues being studied.

Therefore, any statement about wars, people, countries or acts to be good, bad, acceptable, productive, rightfulness, and the like will be noted. The researchers will try to be sensitive to anything ideological about wars, The Second Word War, and its components.

\section{Data Gathering Process}

The gathered data will be the words and phrases heard or seen in the films and noted during the data-gathering process. We will write down the words and phrases regardless of the frequencies of their appearance (if this is not a quantitative research and we do not seek to generalize the findings).

After all relevant data extracted from the films, all pieces of information that look irrelevant will be omitted. Then, the data will be organized through further eliminating, grouping and classifying. The final classified data should show us what questions/issues asked/raised in the films regarding the issue of legitimacy and how they were answered/addressed.

Highly subjective understandings that one can reach it by complicated processes of reasoning and deduction will not be included. We will try to limit the gathered data to direct and obvious suggestions by the films. For instance, we will avoid describing the characters and arguing who was pictured as a better person. But we mention a point about the role if it is directly described in the texts or dialogues. For the same reason, we will not try to analyze the stories and the events to make abstract conclusions.

Such methodological guideline limits the data-gathering process, but it can be highly constructive in improving the reliability of the study and can also help keep a certain level of objectivity. In such qualitative studies, it will 
be hardly possible to claim that one has eliminated subjectivity. However, limiting the data-gathering process to relatively direct-objective data can help us avoid overwhelming complexity.

\section{Results}

We followed the above-mentioned guidelines to break the movie content into clear concepts regarding the war and its legitimacy. The results of the analysis show that the films addressed at least eight sets of concepts related to the issue at hand. The ideas are presented and described below.

1) The situation in which the U.S. entered the war

The situation in which a country decides to enter a war has a crucial role in the judgments passed regarding its legitimacy. Violent actions are usually not justifiable in typical situations. Desperate situations, on the other hand, may justify actions that are not accepted in cases in which things are under control.

The Movies addressed the situation in which the U.S. decided to take part in The Second World War, for instance by calling them dark days. If a country is pictured as one that stepped up as a savior in dark days and desperate situations, even its violent actions may be acceptable.

2) What Americans did in the war?

Many lines and dialogues in the movies dedicated to describing the actions of the U.S. soldiers. The films said the Americans wrote a bright page of American history; they wrote a brilliant page of history; they made victory; they raised the American flag as historic moments, and they made a lasting impression on the world and the American people. They also traded real estate for men.

The phrases do not refer to specific actions conducted by American soldiers. Rather, they are poetic lines praising the role that American army played in the war. In the study of legitimization of wars through cinema, one factor (or set of elements) that can/should be investigated would be the way the conduct of a group was evaluated and presented in the movies.

3) What kind of person an American soldier is likely to be?

The way a soldier of war is pictured in a movie may be one of the oldest and the most classic ways of imagining different sides of a conflict as right or wrong/legitimate or illegitimate. The soldiers of the worst aspect of the war are more likely to be pictured as cruel, unethical people who enjoy unnecessary violence. Soldiers of the right aspect of the war, on the other hand, are more likely to be ethical people, engaged in violence against their will only to achieve a higher or necessary goal.

The movies studied in this research, pictured American soldiers as wise, inspired, eager, young, loyal, courageous, skills in their professional lives, valorous, kind and gallant. The soldiers pictured as people who laugh, volunteer to take part in the war, and follow the values of humanity. The way the soldiers fighting for a side of a war introduced is a good indication if that side of the war is being questioned or legitimized.

4) What kind of person an enemy soldier is likely to be?

Similar to what's mentioned above, the way the soldiers of the other side of the war are pictured can be indicated if a country's role in a war is being legitimized or questioned. In the movies studied in this project, enemy soldiers could torture captured soldiers or walloped a beggar. Their enemies of the war were those who kill millions of people for no reason.

5) How taking part in the war is evaluated?

The content of a movie can evaluate the act of taking part in the war, positively or negatively. In the studied films, for instance, participating in the war was introduced as a responsibility and also a necessity for Americans. Similar statements can be a clear indication if the film is trying to legitimize or question the war and the role a party took in it.

6) What this war is?

The war can be directly evaluated by the statements referred in the movies. Such statements can show the official position a film is taking regarding war. For instance, in the investigated movies, the Second World War was described as a war against Fascism, and also a war that no one wants but the Nazis. The war was also mentioned to be a war to keep America's honor clean and make the world free.

7) How justified was the war?

Whether the war was justified or questionable can be directly addressed in a movie. Some statements from the movies directly introduced the war as a justified one. For instance, it mentioned that the logic of taking part in 
the war is magnificent. Other statements tried to justify the war using a particular logic or justification. For instance, in the movie dialogues, it argued that the war was justified because there were no other solutions left but fighting.

8) What the positive aspects of this war are?

Another way to justify a war is to say it's not all evil, and although violence is wrong, it has its upsides. A statement in the movies said the war contributed to the development of science. Another report said the war taught us a lesson not to let a similar vicious power rise.

\section{Conclusion}

Did America choose to take part in the Second World War? Did America have the right to fight in that war? Did Americans fight the good enemy? Did they use acceptable methods in the war? The present study was not to answer these questions; it's aimed at understanding how cinema's representations of these issues are.

If American cinema tried to legitimize America's presence in the Second World War, what questions would it try to address? The eight major concepts that extracted from the analysis of the content of the movies can be used to perform comprehensive studies on whether or not American cinema tried to justify the war. If fact the eight concepts could be used to design studies aiming at investigating the way other wars were pictured.

The films that can/should be studied to judge if the cinema of a country or a period tried to justify one's role in a war are not limited to the films classified within what is known as a war film and then in particular films in the post-war years. However, one might guess the amount of data related to these issues would be more in a war cinema.

The study conducted on nine films provided a basic guideline for researchers to prepare a questionnaire to explore the way movies may legitimize a war. However, researchers may decide to add some concepts to the eight ideas suggested by this study.

Due to the qualitative nature of this study, we cannot make any judgments, whether the movies justified or questioned the war. However, what is evident is the issues related to the legitimacy of war frequently addressed.

The researchers have evidence to say probably the movies were overwhelmingly pro-war and pro-justification. For instance, controversial issues such as the use of atomic bombs on Japanese cities were never addressed in the films. There were almost no statements that questioned the war or the legitimacy of America's role in it unless by negative characters of the films. However, no matter how much the researchers are confident about these claims, they cannot be considered as the outcomes of the study.

Qualitative research with no careful and scientific sampling and no thorough and systematic way of content analysis cannot arrive at generalized conclusions such as the above-mentioned ones. Therefore, at this point those claims can be at most speculations with some evidence. Such thoughts are good enough to be the basis/hypotheses of other carefully designed studies.

When one of the eight issues was addressed in the films, sometimes it was not raised as a question, but a definite confirmation of the legitimacy of the United States' role in the war. In some cases, the issue was put forward as a question, but it got an answer that confirmed the legitimacy of America's role in the war. In The Best Years of Our Lives, the war was issued by a person who believed America fought a wrong war. This person didn't get a straight answer, but he received a punch from an active character in the movie and got knocked on the floor.

\section{Discussion}

In societies where the gap of legitimacies syndrome is more severe, governments may see a greater need to manipulate the beliefs of the masses making them believe in wars. Where people do not believe in wars States, have at least four critical issues regarding any wars they are engaged in it.

1) Lack of public support may put politicians who want to start or continue a war under a lot of pressure. When people are unsatisfied with the decision of the governments, it becomes very hard for officials to continue with unpopularity. If the country under question is a democracy, the situation can be made more critical more quickly.

2) Wars need human resources. If a war is unjustified and unpopular, fewer people would be ready to sacrifice their lives for it.

3) Wars impose huge expenses on societies. People do not sacrifice their money to help unpopular wars. Massive all out wars usually need a lot more money than governments can provide from the annual budgets.

4) The morale of the soldiers and all those engaged in wars is affected by the perceived legitimacy and popularity of the wars. There are many stories about heroes who made miracle-like sacrifices in wars because 
they sincerely believed in the war and thought the outcomes of the war is far more important than their lives.

Movies are among relevant media contents that affect people's minds regarding the legitimacy of the wars. They are also powerful channels of communication between governments and other sources of power that may see a need to change public opinions regarding war.

Studies such as the present study and quantitative studies that can judge if cinema tried to legitimize a war, can clarify the ways and the extent that film and other media forms got involved in projects or processes of war legitimization.

They can also show what specific ideas the society was exposed. If different studies reveal what society thinks about wars and also what has communicated the community, a lot can be learned about the current ideas among the population and how they were formed.

\section{References}

Agiesta, J. (2015, 9 13). Poll: Americans skeptical Iran will stick to nuclear deal. Retrieved June 6, 2016, from http://edition.cnn.com/2015/09/13/politics/iran-nuclear-deal-poll/

Baum, M. A., \& Potter, P. B. (2008). The Relationships Between Mass Media, Public Opinion, and Foreign Policy: Toward a Theoretical Synthesis. Annual Review of Political Science, 39-65. https://doi.org/10.1146/annurev.polisci.11.060406.214132

Bergen, D. L. (2001). German military chaplains in world war II and the dilemmas of legitimacy. Church History, 70(2), 232-247. https://doi.org/10.2307/3654452

Chester, K. L. (2000, January). Rights and Wrongs: Adopting Legitimacy as the Tenth Principle of War. Kansas: School of Advanced Military Studies United States Army Command and General Staff College Fort Leavenworth.

Coakley, M. (2010). On the value of political legitimacy. Politics, Philosophy and Enonomics, 345-369.

Crawford, N. C. (2016). What is war good for? Background ideas and assumptions about the legitimacy, utility, and costs of offensive war. The British Journal of Politics and International Relations, 18(2), 282-299. https://doi.org/10.1177/1369148115613662

Elo, S., Kaariainen, M., Kanste, O., Polkki, T., Utriainen, K., \& Kyngas, H. (2014). Qualitative Content Analysis : A Focus on Trustworthiness. Sage Open, 1-10. https://doi.org/10.1177/2158244014522633

Entman, R. M. (2004). Projections of Power: Framing News, Public Opinion, and U.S. Foreign Policy. chicago \& London: the University of Chicago Press.

Fabre, C. (2008). Cosmopolitanism, just war theory and legitimate authority. International Affairs, 963-976. https://doi.org/10.1111/j.1468-2346.2008.00749.x

Falomir-Pichastor, J. M., Staerklé, C., Pereira, A., \& Butera, F. (2012). Democracy as Justification for Waging War: The Role of Public Support. Social Psychological and Personality Science, 3(3), 324-332. https://doi.org/10.1177/1948550611420172

Gillespie, M. (2006). Security, Media, Legitimacy: Multi-Ethnic Media Publics and the Iraq War 2003. International Relations, 20(4), 467-486. https://doi.org/10.1177/0047117806069408

Hadeshian, S. (2006). Public Opinion; The role of Media. Toronto: Ccr International Refugee Rights Conference.

Herman, E. S., \& Chomsky, N. (1988). Manufacturing Consent: The Political Economy of the Mass Media. The Political Economy of the Mass Media.

Horten, G. (2011). The Mediatization of War: A Comparison of the American and German Media Coverage of the Vietnam and Iraq Wars. American Journalism, 29-53.

Kumm, M. (2004). The Legitimacy of International Law: A Constitutionalist Framework of Analysis. The European Journal of International Law, 907-931. https://doi.org/10.1093/ejil/15.5.907

Lacy, M. J. (2003). War, Cinema, and Moral Anxiety. Sage, 611-636.

Levy, Y. (2010). The Gap of Legitimacies Syndrome: A Conceptual Framework. International political Science Review, 77-94. https://doi.org/10.1177/0192512109347211

Lynch, J. (2007). Memory and Matthew Shepard; Opposing Expressions of Public Memory in Television Movies. Journal of Communication, 31(3), 222-238. https://doi.org/10.1177/0196859907300948 
Mueller, J. (2005). Force, Legitimacty, success, and Iraq. British International Studies Association, 109-125.

Ramsbotham , A., \& Wennmann, A. (2014). Legitimacy and peace processes From coercion to consent. London: Conciliation Resources.

Rastegar, K. (2015). Surviving Images:Cinema, War, and Cultural Memory in the Middle East. Oxford: Oxford University Press. https://doi.org/10.1093/acprof:oso/9780199390168.001.0001

Rothstein, B. (2009). Creating Political Legitimacy: Electoral Democracy Versus Quality of Government. American Behavioral Scientist, 53(3), 311-330. https://doi.org/10.1177/0002764209338795

Vergne, J.-P. (2011). Toward a New Measure of Organizational Legitimacy: Method, Validation, and Illustration. Organizational Research Method, 484-502. https://doi.org/10.1177/1094428109359811

\section{Copyrights}

Copyright for this article is retained by the author(s), with first publication rights granted to the journal.

This is an open-access article distributed under the terms and conditions of the Creative Commons Attribution license (http://creativecommons.org/licenses/by/4.0/). 